\title{
EXTRAMETRICALITY AND STRESS IN SPANISH AND ITALIAN
}

\author{
Els DEN OS
}

Institute of Phonetics Utrecht, The Netherlands

\author{
René KAGER* \\ Institute De Vooys Utrecht, The Netherlands
}

Received January 1986

In Harris (1983) an analysis of Spanish stress is proposed in which the notion 'extrametricality' plays a crucial role. The constraints on extrametricality presented there differ from the ones proposed by Hayes (1981) in that they refer to a morphological domain instead of a stress domain. This implies that in Harris' analysis the domain of the Peripherality Condition and stress no longer coincide, resulting in weakening of the theory of stress. In the present analysis of Spanish stress we take Harris' proposal as a starting point, but we show that Hayes' original interpretation of extrametricality must be maintained. To this end we introduce a type of rule as used by Archangeli (1984) for Yawelmani, which assigns extrametricality at the stress domain, triggered by a diacritic on stems. This rule enables us to express some generalizations about Spanish stress left unnoticed by Harris. In the last part of this article it is shown that the same principles for stress assignnent which were formulated for Spanish can be extended to Italian with sume language-specific modifications.

\section{Introduction}

The notion 'extrametricality' has become of increasing importance in metrical theory since its introduction by Liberman and Prince (1977). By extrametricality stress patterns which diverge at the surface level may be unified at a deeper level. In this way the notion 'possible stress rule' can be constrained considerably. Thus, extrametricality allows Hayes to explain ternary feet in languages which in principle have a bounded (maximally binary) stress rule.

* Our thanks go to Egon Berendsen, Yvonne Bordelois, Marcel van den Broecke, Wim de Haas, Ben Hermans, Mieke Trommelen, Ellis Visch, Wim Zonneveld, and two anonymous reviewers for their valuable comments on earlier versions of this article, some of which have lead to considerable improvements. Of course, all responsibility for the final text is ours. 
Extrametricality is only able to fulfill such an important theoretical function, if it is constrained itself. In recent literature the exact nature of the constraints is a regularly returning topic of discussion. Hayes (1981) suggests the following three constraints:

- Only phonological or morphological constituents (segments, rimes, affixes etc.) can be extrametrical.

- Extrametricality is a lexical property of specific elements, or is assigned by rule.

- Extrametrical elements are peripheral in the stress domain.

Opinions differ as to the exact definition of peripherality. According to Hayes' interpretation of the Peripherality Condition (from now on PC), an extrametrical element will lose its extrametricality if it is not peripheral in the domain of the stress rule (Hayes (1981: 195)):

(1) $\mathrm{X} \rightarrow[-$ ex $] /[Y]_{\mathrm{D}}$ where $\mathrm{Y} \neq \varnothing$ and $\mathrm{D}$ is the domain of the stress rules

Harris (1983) formulates the PC in a somewhat different fashion: extrametrical elements will lose their extrametricality if they are separated from the edge of their morphological domain by another element at the same level of representation (Harris (1983: 105)):

(2)

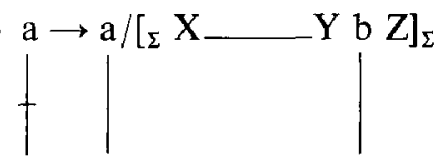

For Harris, the relevant domain is morphological and this domain does not necessarily coincide with the stress domain. Actually this is a weaker interpretation of peripherality than Hayes', since several extrametrical elements may uccur in the stress domain, if only they are peripheral in their morphological domains.

In this paper we will present an analysis of primary stress in Spanish and Italian which will demonstrate that Hayes' stronger interpretation of peripherality must be maintained. In section 2 Harris' analysis of Spanish stress will be reviewed and criticized, in section 3 an alternative analysis of Spanish stress will be given in which extrametricality is assigned by a rule which itself is triggered by a diacritic on stems. In section 4 , this analysis will be extended to Italian; it will be shown that Spanish and Italian, two related languages, 
basically have the same main stress rule, and that they only differ with respect to quantity sensitivity, and permitted entities of extrametrical elements.

\section{Harris' analysis}

\subsection{Data}

Primary stress in Spanish falls on one of the last three syllables of a word. The occurrence of all stress patterns are given in table 1 .

Table 1

\begin{tabular}{|c|c|c|c|c|}
\hline \multirow[t]{2}{*}{ Stressed on } & \multicolumn{2}{|l|}{ With class marker } & \multicolumn{2}{|c|}{ Without class marker } \\
\hline & Non-branching penult & Branching penult & Consonant-final & Vowel-final \\
\hline Penult & $\begin{array}{l}\text { 1. sabána } \\
\text { melóso } \\
\text { alemána } \\
\text { gacéta } \\
\text { dinéro }\end{array}$ & $\begin{array}{l}\text { 4. alérta } \\
\text { sosiégo } \\
\text { carámba } \\
\text { redónda }\end{array}$ & $\begin{array}{l}\text { 7. caníbal } \\
\text { jóven } \\
\text { cráter } \\
\text { huésped } \\
\text { orígen }\end{array}$ & 10. - \\
\hline Antepenult & $\begin{array}{l}\text { 2. sábana } \\
\text { múltiple } \\
\text { número } \\
\text { métrico } \\
\text { fúnebre } \\
\text { huéspede }\end{array}$ & 5. - & $\begin{array}{l}\text { 8. régimen } \\
\text { ómicron } \\
\text { espécimen } \\
\text { ínterin }\end{array}$ & 11. - \\
\hline Final & 3. - & 6. - & $\begin{array}{l}\text { 9. civí] } \\
\text { alemán } \\
\text { mujér }\end{array}$ & $\begin{array}{l}\text { 12. Panamá } \\
\text { dominó } \\
\text { convóy } \\
\text { Abréu }\end{array}$ \\
\hline
\end{tabular}

In Spanish a distinction must be made between words with a class marker (from now on $\mathrm{CM}$ ) - an inflectional, mostly vocalic ending which indicates morphological gender - and words without a class marker. The difference between these types of words is shown in the plural and in derivations. Words with a $C M$ only have the plural suffix $-s$, whereas words without a $C M$ in most cases have -es, compare saban) $a-s$, where the final $a$ is a $\mathrm{CM}$, with domino)-es, where no $\mathrm{CM}$ is present. The $\mathrm{CM}$ never occurs inside derivational suffixes, compare $[($ cas $) a]-[(($ cas $) e r) o]$ with $[($ domino $)]-[($ (domino $)$ cer $) o]$. Stems will be indicated by $(\ldots)$, words by [...]. In words with a CM, like the final $a$ in $[($ saban $) a]$ 'savanna', stress mostly falls on the penultimate syllable ( 1 in the 
table), sometimes on the antepenultimate syllable (2), but never on the final syllable ( 3 and 6 ). When the penultimate syllable is closed or contains a glide (in other words, when the rime is branching) stress always falls on this syllable (4): [(alért)a] 'alert', [(sosiég)o] 'rest' ( ${ }^{*}$ álerta, * sósiego (5)). Words without a $\mathrm{CM}$ may either end in a consonant or in a nonconsonantal element, vowel or glide. Words ending in a consonant mostly have stress on the final syllable (9) [(civil)] 'polite', [(alemán)] 'German', sometimes on the penult (7), [(cráter)] 'crater', [(canibal)] 'canibal', and, very rarely, on the antepenult (8) [(régimen)] 'government'. Words ending in a vowel or glide are all stressed on their last syllable (12) [(Panamá)], [(dominó)] 'dominoes', [(convóy)] 'convoy', [( Abréu)] (name of a town).

\subsection{Harris' (1983) analysis}

\subsubsection{Noncyclic cases}

Harris assumes the stress domain in Spanish to be the word. Derivational suffixes are attached to the (derivational) stem, i.e. the word without the CM, if present. The word is also the domain of syllabification. Syllabification must precede the stress rule, since stress in Spanish is quantity-sensitive, i.e. sensitive to branchingness of the rime:

(4)

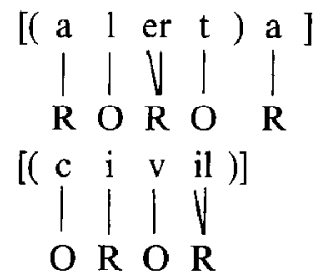

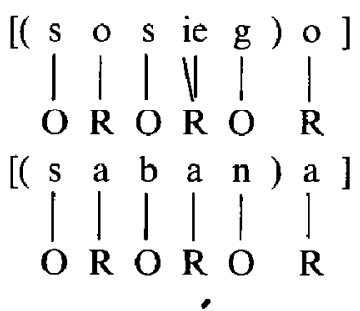

After projection of rimes the stress rule (5) gives the 'unmarked' stress patterns for words of the type exemplified above:

(5) Stress rule

Form left-dominant, quantity-sensitive, maximally binary feet on the rime projection from right to left. The word tree is right-branching, labelled $w-s$. 
In the representations below $\mathrm{R}$ indicates the rime level and $\mathrm{F}$ the foot level:

(6)

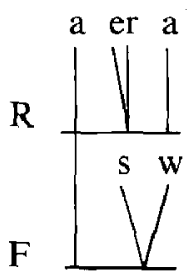

$V^{s}$

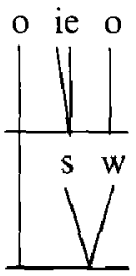

$V^{\mathrm{s}}$
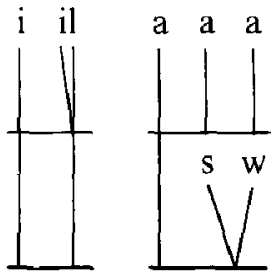

$V^{\mathrm{S}}$

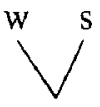

In order to account for forms like sábana 'sheet', canibal and jóven 'young' on the one hand, and to exclude forms like (hypothetical) *álerta, *sósiego and *ánibal on the other hand, Harris assumes that segments may be extrametrical. In the examples below extrametricality is indicated at the segmental level by ' $/$ ', and at the rime level by '-'. For example:
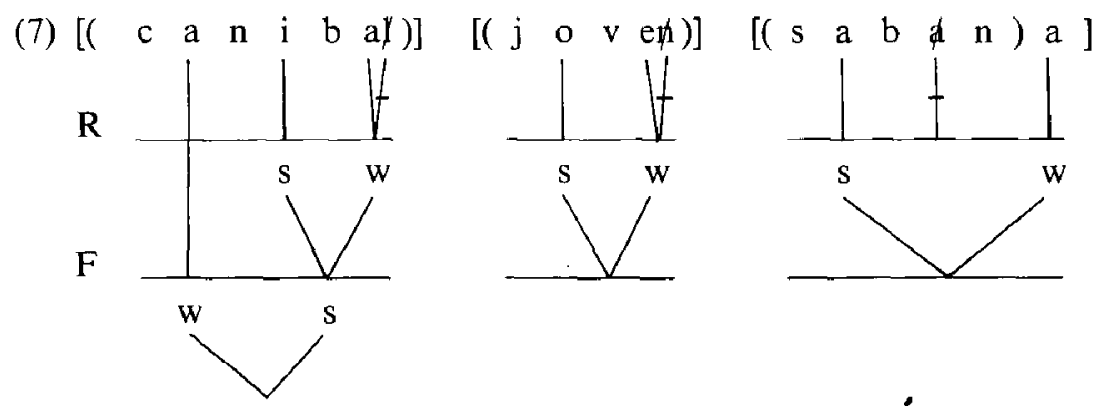

The stress rule applies as if the last rime in canibal and joven were not branching. Forms like *ánibal are excluded correctly by Harris' assumption that in Spanish only segments, not entire rimes, may be extrametrical, and moreover, that the extrametrical segment must be at the edge of a morphological domain. If more than one segment should be extrametrical within the same morphological domain, the PC (2) wipes out the extrametricality on all nonperipheral segments:

(8) $\left[\left(\begin{array}{llllll}c & a & n & j & b & a\end{array}\right)\right] \rightarrow\left[\left(\begin{array}{cccccc}c & a & n & i & b & a l\end{array}\right)\right]$ caníbal $\left[\left(\begin{array}{cccccc}c & a & n & i & b & l l\end{array}\right)\right] \rightarrow\left[\left(\begin{array}{cccccc}c & a & n & i & b & \text { al }\end{array}\right)\right]$ caníbal 
In sábana the stress rule applies as if the second stem vowel were not there. According to Harris, this segment may be extrametrical, since it is the last rime segment in the derivational stem. Onset segments are allowed between extrametrical segments and the edge of a morphological domain, because these onset segments do not belong to the same level of representation as rime segments. Because of the fact that the derivational stem is a distinct morphological domain (although not the stress domain), the PC (2) must allow this marking:
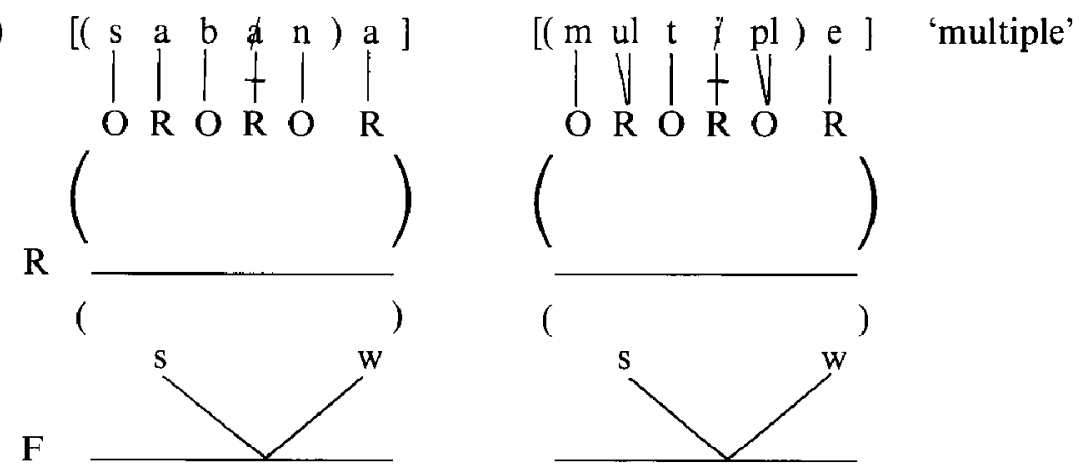

After the main stress rule has applied, extrametrical rime segments are adjoined as weak members by a universal adjunction convention (SSA: Stray Syllable Adjunction); extrametrical consonants are adjoined to the rime (see (7)), and vowels to the foot (see (9)).

In this analysis, extrametricality is rightly considered as a property of (segments in) stems, and possibly derivational suffixes. This is in agreement with the observation that addition or change of a $\mathrm{CM}$ never influences the position of main stress:

$\begin{array}{lll}\text { (10) alemán - alemána } & \text { 'german male/female' } & *\{\text { alemán - alémana } \\ \text { múltiple - múltiplo } & \text { 'multiple' } & * \text { múltiple - multíplo } \\ \text { métrico - métrica } & \text { 'metrical' } & * \text { métrico - metríca }\end{array}$

Additional arguments are presented by Harris to regard the derivational stem as a domain for the PC needed independently of the word domain. The derivations of the correct forms of tórax 'thorax', prótasis 'protasis', and análisis would be impossible if only their final segments could be legitimately extrametrical: 
(11)

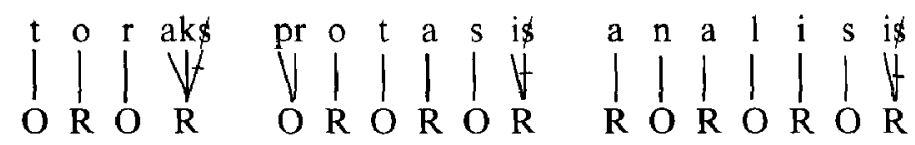
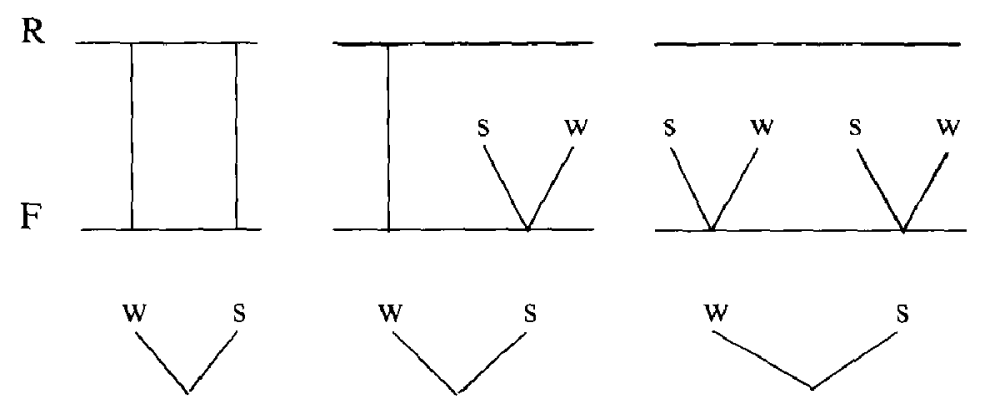

The stress rule would yield *torax, *protásis and *analisis instead of the correct forms. However, according to Harris the $-s$ in torax and the ending $-i s$ in protasis and analisis can be considered as CM's. The final consonants are (predictably) extrametrical because of a rule assigning extrametricality to all consonants outside the derivational stem. In addition, the last rime segments in the stems are lexically marked as extrametrical. For Harris, this demonstrates the need for multiple extrametricality within the stress domain, i.e. both within the derivational stem and within the word, as shown in (12):

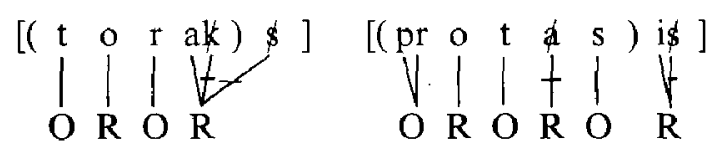

R
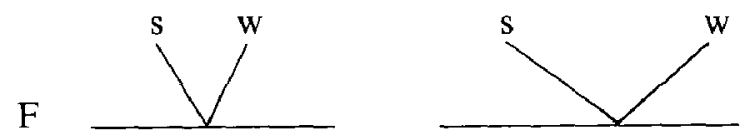

The class of words ending in non-CM vowels and glides remains to be accounted for. To these words, a foot is redundantly assigned: 
(13) Strong Foot Rule

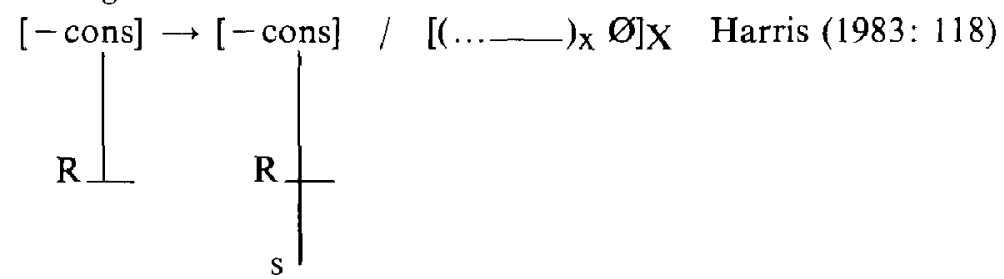

\subsubsection{Cyclic stress assignment}

Addition of a plural suffix - $(e) s$ never leads to a shift of the main stress, except in some marginal cases like ómicron-omicrónes 'omicron', régimen-regimenes, carácter-caractéres 'character'. The relevant cases thus are sabána-sabánas, sábana-sábanas, alemán-alemánes and canibal-canibales. Since the word is the cyclic domain, pluralized words contain two cyclic domains:

\section{(14) $[[($ saban ) a ] s ] [[( canibal )] es ]}

Under the assumption that existing structure is preserved as much as possible, the derivations yield the correct results. It is important to note here that for Harris the $-s$ of the plural suffix is predictably extrametrical like any other consonant outside the derivational stem. Though on the outer cycle a foot is assigned to the suffx vowel $-e$, this foot will be adjoined to the main stress foot as a weak element by SSA. This is shown in (15); notice that the stem-final consonants of aleman, canibal are syllabified on the outer cycle as onsets and thus become stress-irrelevant:

(15) Inner cycle
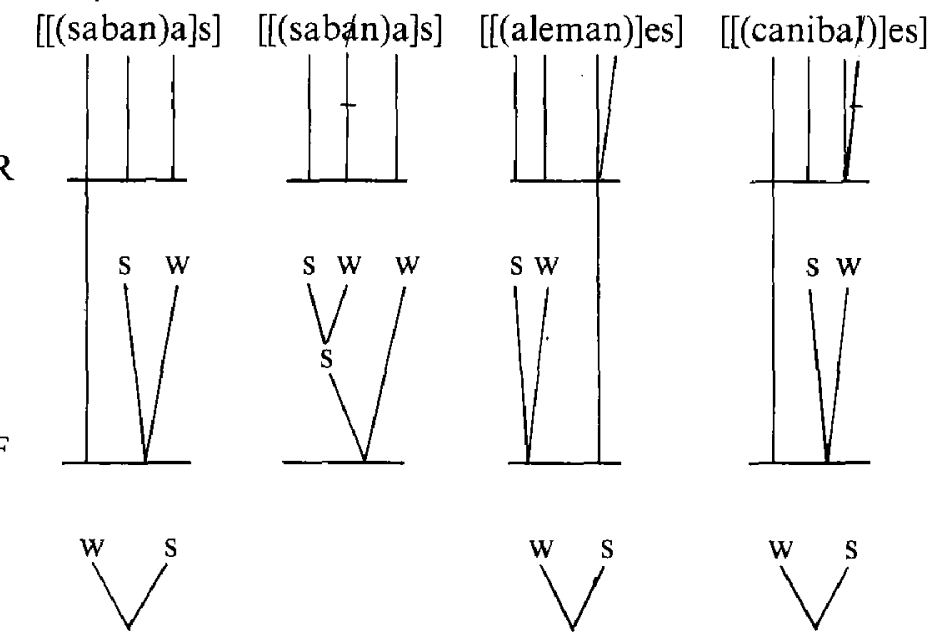


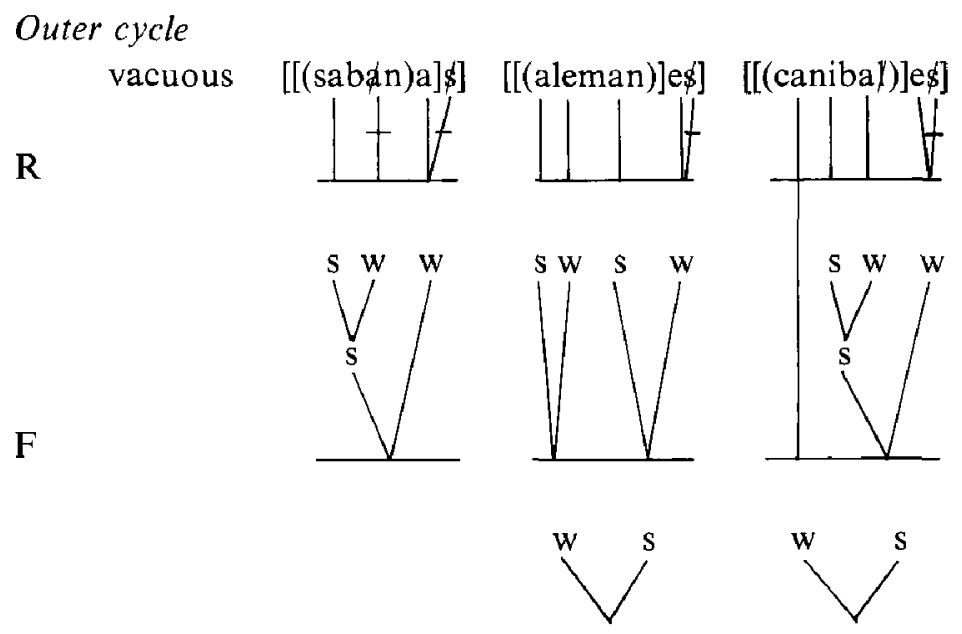

\subsection{Shortcomings of Harris' analysis}

In our view, there are two major problems for Harris' analysis. The first problem concerns the discrepancy between the domains of stress assignment and the $\mathrm{PC}$, and, in relation to this, the way of representing extrametricality (section 2.3.1). The second problem has to do with cyclic stress assignment in plural forms (section 2.3.2).

\subsubsection{Domains and representations of extrametricality}

Harris convincingly shows that the syllabified word must be the domain of the stress rules. Indeed, an appeal to syllable structure is essential to explain the difference between (fúnebr)e, (múltipl)e and * (cáramb) a, (álert) a. It is also clear that extrametricality has to be a property of the stem, as Harris demonstrates. However, Harris' solution to allow extrametricality of the rightmost rime segment in the derivational stem (for cases like múltiple etc.) strictly spoken means that morphological bracketing has to be inspected within the larger domain of the word, to which phonological rules (such as syllabification) have already applied. Thus, the notion 'peripheral within the syllabified derivational stem' is a rather awkward one, since it is not the derivational stem which is syllabified, but the entire word. If peripherality was to be checked on the derivational stem, it is expected that reference to syllable structure is not yet possible, and that extrametricality of $i$ in multiple is blocked by the segments $p l$ within the same domain. Stated differently, on the one hand Harris assumes a morphological domain (multipl) and on the other hand a phonological interpretation of peripherality on this domain, i.e. 
syllable structure, which is itself dependent on a larger domain, viz. the word. We prefer an analysis in which the domains of syllabification, stress assignment and the PC coincide. This would also result in a stricter interpretation of the PC by the explicitly demanded equation of the domain of stress assignment and the domain on which stress-relevant exception markings may take effect. Harris' way of marking extrametricality in the lexicon is also problematic. His analysis accounts for the neutrality of CM's with respect to stress within pairs like múltiple - múltiplo etc., because the same stem segment in the same derivational stem is extrametrical for both members of the pair. That is, the stem (multipl) has a lexical marking for extrametricality on the segment $i$. However, marking a specific stem segment as extrametrical in the lexicon has some disadvantages. Firstly, it is absolutely arbitrary, lexically speaking, which segment is marked as extrametrical. In principle it could also have been the $p$ or the $l$. It is only because these segments will be syllabified as onsets that their extrametricality will not have an effect. The fact that final rime segments in the stem have to be lexically marked is a side effect of the use of the rime projection together with the PC. It must be concluded that the lexical marking of specific segments in the lexicon together with the PC results in redundancy, thus diminishing the explanatory power of the analysis.

The second disadvantage of lexically extrametrical segments is revealed when comparing pairs of words originating from the same stem, one of which has a CM, whereas the other does not: alemán-alemána 'German male/ female'. For Harris it is completely accidental that no pairs like *alemán-alémana exist. In other words, his theory could handle the following nonexisting situation. Firstly, suppose that the final $a$ in the hypothetical stem aleman is lexically marked as extrametrical, this would have no effect in the word alemán, since the $a$ is not peripheral within the stem. But the extrametricality of the $a$ would have effect in the word alemana since here it is peripheral within the stem. Secondly, suppose that in another hypothetical stem aleman the $n$ is lexically marked as extrametrical. This would have an effect in the word aleman, but not in the word alemana, since here the $n$ is syllabified as an onset. However, pairs like *alemán-alémana and *aléman-alemána do not exist in Spanish. Only non-shifting pairs occur:

(16a) huésped-huéspeda césped-céspede

(16b) alemán-alemána inglés-inglésa 'guest male/female'

'lawn-lawn'

'german male/female'

'englishman/-woman' 
The use of double domains with respect to the PC (word and stem) has more disadvantages. Notice that Harris' analysis is theoretically compatible with representations like (17):

\section{(17) [(aleł̣t) ád] (*álerta)}

The hypothetical form álerta is derived if both a specific stemsegment $(r)$ and a CM are extrametrical. In Harris' analysis the absence of these forms in Spanish is the result of the coincidental corresponding absence of extrametrical CM's, and is thus not explained principally.

Finally, stress assignment to monosyllabic stems with marked segments is problematic. Stems as in -tes + is, -fras $+i$, and -metr $+o$ must have lexically extrametrical stem vowels in order to derive the correct stress in forms like (18), as cited from Whitley (1976):

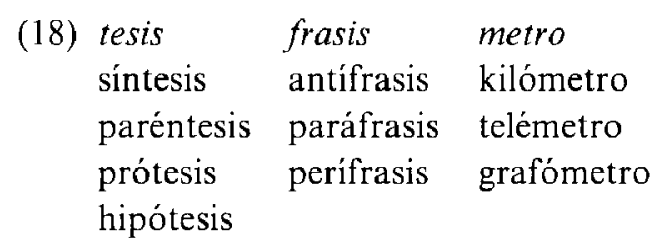

The final consonant $s$ is predictably extrametrical. In addition, the peripheral rime segment has to be extrametrical in order to receive stress on the antepenultimate syllable, e.g. $[(\sin +t \phi s) i \xi)]$. The lexical representations of the stems are thus $(t \phi s),(f r \phi s)$, and (mфtr). However, tésis, frásis, and métro also exist as single words, with stress on the stem. If it is assumed that these stems have extrametrical vowels, this results in ungrammatical forms: *tesis, *frasis, *metró (cf. (19)):

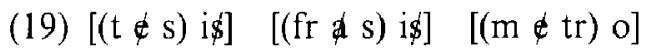

These problems can only be avoided by a condition like (20):

(20) The extrametricality of a segment is wiped out, if this segment is the only stressable segment (vowel) in the derivational stem.

A similar condition was proposed by Hayes (1982) for extrametricality of rimes in monosyllabic words, e.g. in Latin and in English nouns: 
(21) Extrametricality rules are blocked if their application would mark the entire stress domain as [+ex]. (Hayes 1982: 235)

With respect to the examples above, Harris cannot refer to the stress domain, since in this domain there are still stressable elements left, i.e. the CM's. The derivational stem must therefore be mentioned specifically. In itself, this would be unproblematic if (20) were to refer to any morphological domain, derivational stem or word, just like the PC. However, (20) must refer to the derivational stem only.

Summarizing, lexical marking of specific segments results in redundancy because the position of extrametrical segments is on the one hand predictable from syllabification and the PC, and on the other hand is diacritically marked as such in the lexicon. Furthermore there is no explanation for the observation that CM's are stress-neutral within pairs of words in which one word has no CM. Finally, complicating conditions such as (20), conflicting with the PC, have to be formulated.

\subsubsection{Cyclic stress assignment and plural affixes}

A well-motivated assumption in metrical theory (Hayes (1981), Kiparsky (1982)) states that stress rules may destroy structurc on inncr cycles as far as this structure falls within the application of the stress rules on the outer cycle. In addition, extrametricality markings on inner cycles are lost. This follows directly from the PC (see (1)). The derivation of paréntal from párent may serve as an example. Main stress is assigned by the English Stress Rule (ESR):

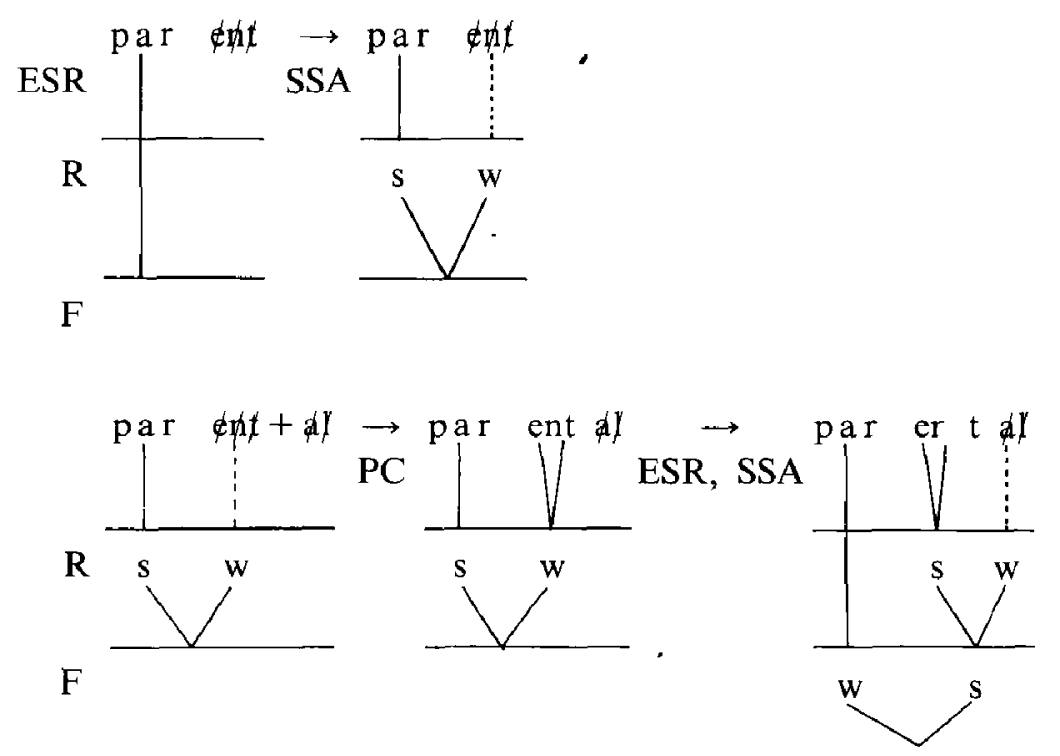


If the derivation of camihales from camihal and -es would take place in a similar manner, the wrong form *caniháles would arise. Notice that in Harris' analysis extrametricality on the inner cycle also disappears; this is the result of resyllabification of the $l$, not of the PC.

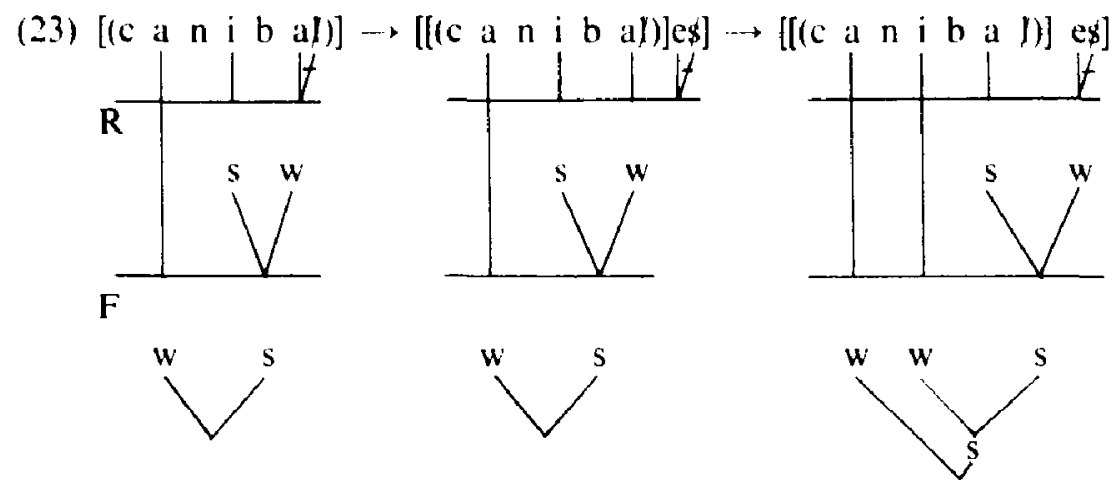

Harris appeals to Kiparsky (1979) when he states that stress assignment is accompanied by a 'minimal change" of the prosodic structure in the embedded cycle. However. Harris does not recognize that minimal change is not equal to no change. Even if the stress rule is not allowed to change the structure in an embedded cycle. there is still a problem. According to Harris, the foot under -e's which results from his derivation in (15) and which is attached to the preceding foot, is 'technically non-branching' (1983: 125); technically spoken. however, only the rime (not the foot) is non-branching. It is generally accepted that word level labelling cannot refer to branchingness at rime level. This can be illustrated by mujer 'woman', where a non-branching foot is labelled $s$ on the basis of word tree labelling:

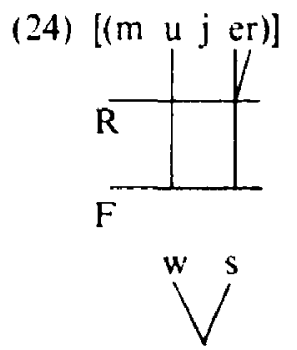

Thus, for Harris it is rather difficult to explain that the plural affix in Spanish is stress-neutral, or in other words seems to violate the PC. 


\section{A new proposal}

\subsection{Singular forms}

In order to circumvent the problems mentioned above, our analysis will have to incorporate the following elements:

- The domains of syllabification, stress assignment, and the PC coincide. The relevant domain will be the word.

- Extrametricality diacritics are lexically marked on stems.

- Pluralization is neutral with respect to stress assignment.

We will propose a solution which corresponds to Archangeli's (1984) treatment of Yawelmani noun stress. ${ }^{1}$ Archangeli assumes that under narrowly specified morphological conditions, noun stems are marked with a rule diacritic [ $+\mathrm{D}]$, triggering the application of rule (25) (Archangeli (1984: 234)):

(25) Noun Extrametricality

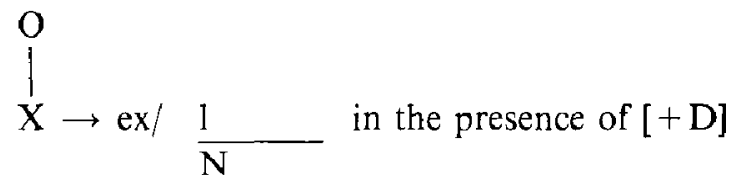

That is, extrametricality is assigned by rule to the first syllable following the $[+D]$-marked stem. In case a disyllabic suffix is adjoined to the stem, extrametricality will be assigned to the first (stem-adjacent) syllable of the suffix, but because it is not peripheral within the domain of the stress rule, extrametricality will be erased. Thus, peripherality will be checked on the extrametrical element itself, and not on the carrier of [+D], the stem. Similar analyses have been proposed for Polish stress by Halle and Vergnaud (forthcoming), Ilayes and Puppel (1985), and Franks (1985). In a footnote, Archangeli (1984: 224, fn. 47) suggests that it may be possible to extend her analysis to Spanish. We will show that it is indeed possible to treat Spanish stress in this way. For Spanish it will be shown that only segments, not syllables, are allowed to be marked as extrametrical. A rule comparable to (25) will mark a

- The expositjon given below will only serve to exemplify the type of analysis we aim at. That is, we do not consider the correctness of the Yawelmani analysis itself. 
segment adjacent to the stem as extrametrical, if this stem carries the diacritic $[+E]$; this rule may be tentatively formulated as in (26):

(26) segment $\rightarrow$ em $/$ )stem $\_$in the presence of $[+E]$

In a word like sábana, the stem-adjacent segment - $a$ (here identical to the $\mathrm{CM}$ ) will be marked as extrametrical. The extrametrical segment will be peripheral within the domain of the stress rule, i.e. legitimately extrametrical with respect to the PC (1):

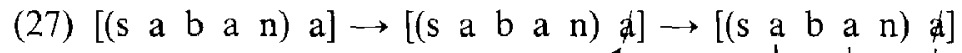
$[+\mathrm{E}]$ $[+\mathrm{E}]$

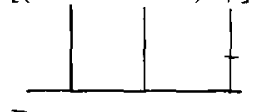

$\mathrm{R}$

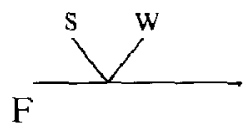

A branching (heavy) penult may never be skipped by the stress rule (because of Q-sensitivity), even if the stem that it is part of carries the diacritic:

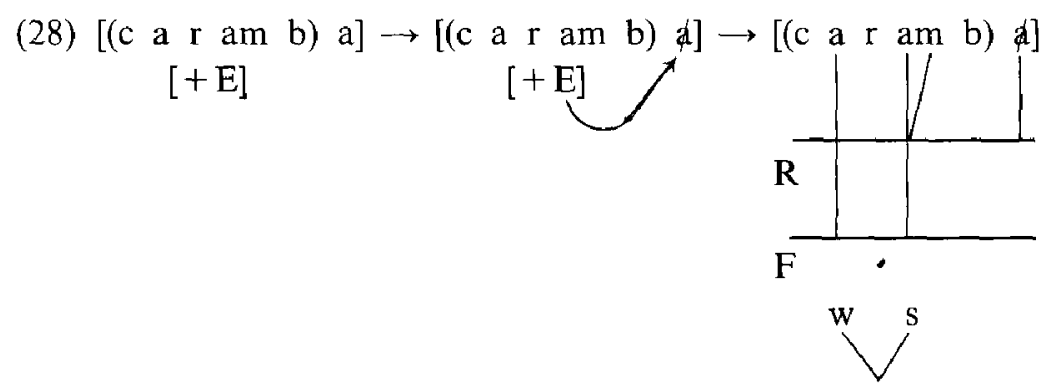

This means that we have a principled way of ruling out forms of the hypothetical type *áramba. Affixes, like stems, may carry the diacritic $[+\mathrm{E}]$. The suffix $-i c$ is an example:

(29) $[((\mathrm{m} \mathrm{e} \mathrm{tr)} \mathrm{i} \mathrm{c)} \mathrm{o]} \rightarrow[((\mathrm{m} \mathrm{e}$ $[+\mathrm{E}]$

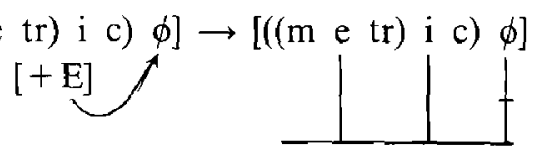

R

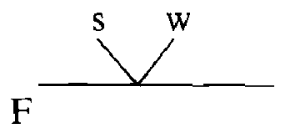


Segments marked as extrametrical by (26) may be filtered out by the PC, in case they are not peripheral in the domain of the stress rule, i.e. the word. The form numeróso may serve as an example. The stem numer must be diacritically marked with $[+\mathrm{E}]$, given the stress pattern numero. In $[(($ numer $)+o s)+o]$, the first segment of the derivational suffix -os will be marked as extrametrical by (26). However, as this segment is not peripheral within the word, the PC erases its extrametricality and the correct form numeróso will be derived:

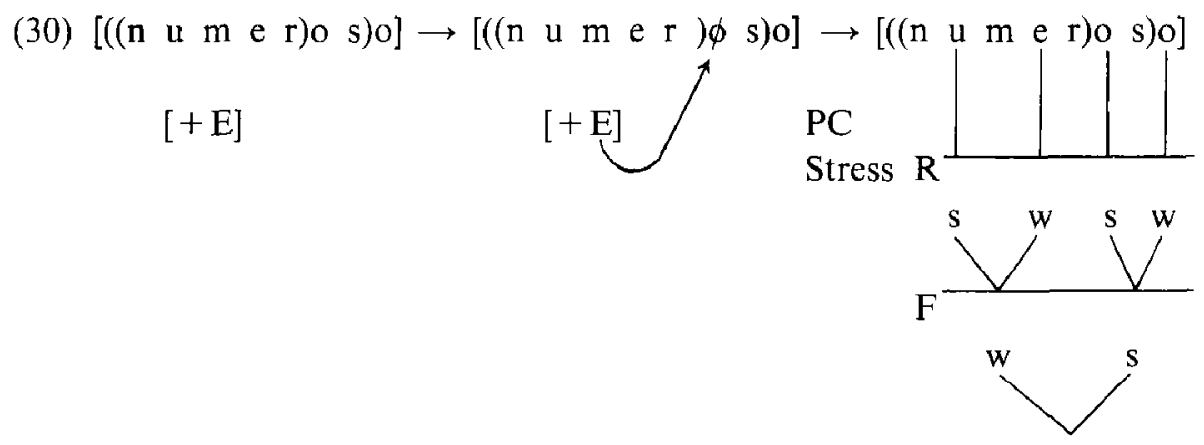

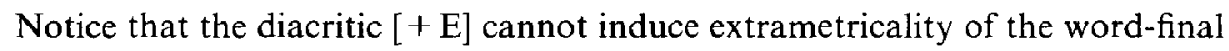
$\mathrm{CM}-o$ because of the non-adjacency between the $[+\mathrm{E}]$ marked stem and the $\mathrm{CM}$. The adjacency between the $\mathrm{CM}$ and the (maximal) derivational stem ( (numer)os) is irrelevant here, because we can assume that the diacritic [+E] does not automatically spread over the entire derivational stem. To support this claim, consider another well-known diacritic in Spanish, the diphthongization diacritic, which behaves identically in this respect. The stem (mel) 'honey' is diacritically marked for diphthongization. Diphthongization applies to stressed vowels in stems marked with the relevant feature $[+D]$ (Harris (1977)). Thus we have miél-melóso, the lack of diphthongization in the second case being due to the absence of stress on the vowel that it should apply to. What is remarkable about meloso however, is that the stressed -o in the derivational suffix -os also does not diphthongize, in spite of the fact that $/ o /$ is a possible undergoer (as can be seen in the forms bueno-bonito). From this it is clear that $[+D]$ cannot spread over the maximal derivational stem.

We now continue our discussion of extrametricality. Consider consonantfinal words like canibal. As a first try, we might lexically mark such stems with an extrametrical final segment (canibal). Now we need a redundancy condition limiting the size of an extrametrical unit to maximally one segment, for both rule-derived and lexically marked extrametricality. Unfortunately, this solution has two serious drawbacks. In the first place, extrametricality would have to 
be lexically marked both on specific segments and on specifix stems (by $[+E]$ ). Harris can avoid this double mechanism by simply having all instances of extrametricality lexically marked on specific segments. Moreover, the distribution of the two types of marking would be rather arbitrary, in that it will always be consonants that are marked lexically and vowels that are marked by rule. This distribution is entirely accidental. In the second place, the same problems as we mentioned in section 2.3.1 with respect to Harris' analysis would reoccur. Recall that there are no doublets like *alemán-alémana, *césped-cespéde etc. in Spanish. The analysis suggested above cannot explain their absence because it treats the consonant-final members of the pairs as lexically independent of the vowel-final members. That is, it would be completely accidental that a lexically marked extrametrical consonant always cooccurs with the $[+E]$ diacritic and vice versa within the same stem. It is exactly this observation that will serve as the starting point for our solution. We will attribute the extrametricality of segments in consonant-final words like canibal, césped to the same type of lexical markings as we did for vowel-final words like sábana, céspede.

Both types will be instances of rule-derived extrametricality, triggered by the [ $\mid$ E] diacritic. We will adjust rule (26) to cover the consonant-final cases as well, so that $[+E]$ can take effect within the stem that it marks:

$$
\begin{gathered}
{[(\mathrm{c} \text { a } \mathrm{n} \text { i b al })] \rightarrow[(\mathrm{c}} \\
{[+\mathrm{E}]}
\end{gathered}
$$
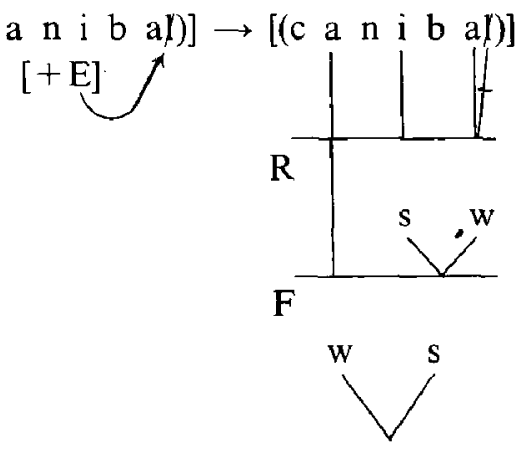

The desired effects can be obtained by rule (32), replacing (26):

(32) If the stem carries [+E], mark segments within the stem and immediately adjacent to the stem as extrametrical.

This minor rule covers all cases that we encountered so far, i.e. vowel-final and consonant-final words. A similar formulation has been proposed by Halle and Vergnaud (forthcoming) for syllable extrametricality in Polish: 
(33) 'Mark as extrametrical the last stem syllable in masc. nouns and the post-stem syllable in fem. nouns.' (Halle and Vergnaud (4.24))

That is, dependent on lexical information (word class, rule diacritic), specified units (syllables, rimes, segments) both inside the stem and immediately following the stem may be marked as extrametrical. ${ }^{2}$ The PC trims all cases of excessively created extrametricality: only word-peripheral extrametrical segments will survive. That is why we can leave unspecified the exact number and position of stem-internal segments that (32) applies to. This solution brings about the connection between consonant-final and vowel-final forms of the same stem. In a pair [césped-céspede], the last consonant or the last vowel will turn out to be extrametrical, due to the fact that the stem is marked with [+E]. The PC gives us one extrametrical segment in each case. As will be clear, the domains of the stress rule and the PC can now be united in the sense of Hayes (1981).

\subsection{Pluralization and level-ordering}

The stress-neutral character of the plural affix -es/-s cannot be accounted for satisfactorily in Harris' analysis, as we have shown in section 2.3.2. In contrast to Harris' claim, cyclic application of the stress rule in pluralized forms will lead to stress shifts with respect to the singular forms (canibal/*canibáles). We need a way to exclude the plural affix from the domain of the stress rule, and we submit that the best way to achieve this within the present theoretical framework is by level-ordering. An extrametricality approach to the plural affix would incorrectly lead to a violation of the principle that maximally one segment on the word edge may be extrametrical (-es having two segments) and, because of the PC, to the effect that internal extrametricality markings would be erased. In the following lexical model, the word stress rule is limited to the first two lexical strata, and pluralization to the third:

(34)

Level I (stem level): -ic, -os, -ur etc. + word stress

Level II (word level): diminutives, superlatives + word stress

Level III (compound level): compounds, plurals, -mente + compound stress

$z$ Our analysis is in agreement with the situation in Polish and Yawelmani, where maximally one unit (segment, rime, etc.) outside the stem can be marked as extrametrical. This situation needs an explanation, which will not be given here. 
CM's are adjoined after all derivational processes on each level have taken place. It is only after the adjunction of the CM $(-o,-a,-e,-i$, or zero) that cyclic brackets are introduced. Cyclic rules (syllabification, stress rules, etc.) can therefore only apply at the end of a level. The word stress rule is only applied at Levels I and II. The distinction between Level-I and Level-II affixation is well-motivated and relatively undisputed for Spanish, Level-I affixation being stem-based and Level-II affixation word-based. This explains why 'inside' Level-I affixation, no CM's can occur (bon + dad 'goodness', bueno 'good'), and why certain rules of allomorphy can refer to specific stemfinal consonants (as for example, the verbalizing suffix $-i z$ as reported in Hammond (1977)). In contrast, Level-II affixes may be sensitive to the kind, or the presence or absence of a CM, as becomes clear from analyses of the Spanish diminutive: $[($ cort $) e]$ cortecito $\left({ }^{*}\right.$ cortito $)$ 'cut', $\left[(\right.$ cort $)$ o] cortito $\left({ }^{*}\right.$ cortecito) 'cut short' (examples from Harris (1983: 93)), and [(mujer)] mujercita (*mujerita). See for an extensive analysis of Spanish diminutives Jaeggli (1980). Inside Level-II affixes, cyclic stress-dependent phenomena like diphthongization, may occur (for discussion see Harris $(1969,1983)$ ): miél, mielcito (with a Level-II diminutive), but melóso (Level-I-derived by -os), and buéno, buenisimo, bondád (where -isimo is a Level-II superlative and -dad a Level-I suffix). These effects follow from our model since stems do not receive stress before Level-I affixes are adjoined, whereas they have already received stress at the moment that the Level-II affixes are adjoined. Level-II affixes are themselves stressed by Level-II application of the stress rule. At Level-III, or the Compound Level, the plural affix -es/-s and -mente are adjoined. Arguments for the compound status of -mente (like the fact that it permits gapping, like other compounds, but unlike other suffixes) are found in Harris (1983). Adjectives serving as the base for -mente derivation retain their original stress pattern internally, as in the minimal pair lucidaménte 'insightfully', -lúcidaménte 'elegantly' (example from Otero (1985)). -Mente itself will be stressed as a word on its own at Level I, and is consequently stressed as the strong member of a compound at Level III. The plural affix which we assume to be situated on Level III also, cannot be a word on its own, and is therefore excluded from any stress rule, in particular from the compound rule, as it applies to units of word level only. Arguments for the Level-III status of pluralization are based on the fact that it may not occur inside derivational suffixes. An additional argument will be presented below.

In the literature on Spanish stress it is often observed that of the consonantfinal words that do not follow the predominant final stress pattern, many end in $-s$. In this respect, they behave like plural forms in $-s$. Harris observes that 
consonant-final antepenultimately stressed words almost all end in $-s$, with just a few exceptions:

$\begin{array}{lll}\text { (35) parálisis miércoles } & \text { isósceles ángelus } & \text { ómicron } \\ \text { paréntesis } & \text { Sócrates } & \text { régimen } \\ \text { sintesis } & \text { Cáceres } & \text { espécimen } \\ \text { hipótesis } & \text { Lícidas } & \text { ínterin } \\ \text { prótasis } & & \\ \text { génesis } & & \\ \text { antifrasis } & & \\ \text { paráfrasis } & & \\ \text { perífrasis } & & \\ \text { prótesis } & & \\ \text { análisis } & & \end{array}$

Apart from their unusual stress behaviour, the words in (35) ending in -s are exceptional in that they lack separate pluralized forms. Thus, the plural of protasis is protasis. They share this property with a class of words ending in $-s$ and stressed on the penult:

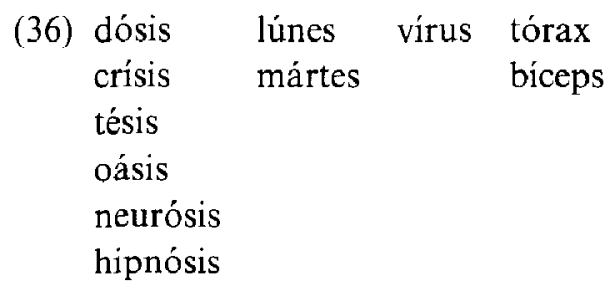

Hooper and Terrell (1976) draw attention to the correspondence between the (singular/plural) ending $-\mathrm{Vs}$ and the plural affix $-(e) s$ with regard to their form and stress behaviour. They represent the words in (35) and (36) as follows (see also Harris $(1980,1983)$ ):

$\begin{array}{lll}\text { (37) stem } & \mathrm{CM} & \text { plural } \\ \text { dós } & \mathrm{i} & \mathrm{s} \\ \text { parális } & \mathrm{i} & \mathrm{s} \\ \text { lún } & \mathrm{e} & \mathrm{s} \\ \text { miércol } & \mathrm{e} & \mathrm{s} \\ \text { ángel } & \mathrm{u} & \mathrm{s}\end{array}$


Thus, they analyze these forms, even if semantically singular, as if they contained a plural affix $-s$, following a $\mathrm{CM}-i,-e,-u$. Pluralized words therefore correspond with the words in $(35,36)$ in three respects:

- they cnd in $-s$,

- they can be stressed on the penultimate syllable in spite of the fact that they end in a consonant (canibal + es / prótasis), and

- they cannot be pluralized morphologically (as opposed to words in $-s$ having final stress: inglés-ingléses 'Englishman sing./plur.')

By analyzing $-s$ in the ending -is/-es as a plural morpheme, we can explain the three correspondences mentioned. From the assumption that the plural affix is outside the domain of word stress assignment by level ordering (as argued above) it follows that pluralization is stress-neutral and that antepenultimate stress in consonant-final words can only occur if these words end in (plural) $-s$. Notice that from this lexical model an empirical prediction follows: if words ending in $-s$ are morphologically derived at Level-III (like all plural forms), no Level-I or Level-II affixes can be adjoined to them. This prediction agrees with the data. Level-I affixes adjoin to the stem, as in paralis + is paralit $+i c o$ 'paralytic', dos $+i s$ - dos $+i f i c a r$ 'dose $\mathrm{N} / \mathrm{V}$ ', analis $+i s$-arnalit $+i c o$ 'analytic'. Level-II affixes such as the diminutive suffix are adjoined to the word without $-s$ (protasito), if they are to be adjoined at all: forms like protasisito are felt to be seriously ill-formed (Y. Bordelois, personal communication). ${ }^{3}$ Within this analysis we are able to account for pairs like tésishipotesis (see section 2.3.1), as will be clear from (38):

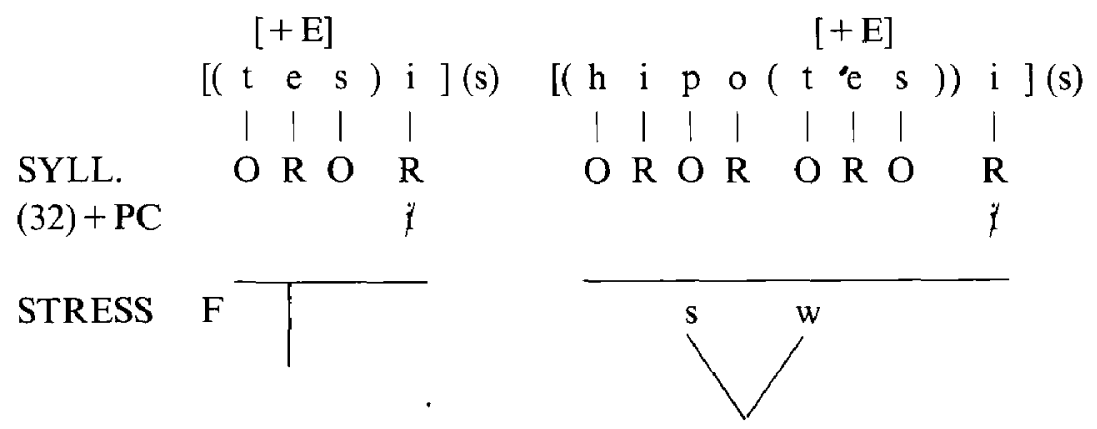

3 However, the names of the days of the week can occur in diminuated forms: lunesito, miercolesito. We suppose that the frequent use of words such as lunes, etc. may be the reason why speakers feel the necessity to diminuate these forms. Diminuation of less frequent words, such as prótasis, remains impossible. 
Only a very limited class of consonant-final words having penultimate stress cannot be accounted for: ómicron, régimen 'government', espécimen 'specimen', and interin 'interim'. There is no evidence to motivate the assumption that $-n$, such as $-s$ in the cases above, is exempt from the stress domain. These words are truly exceptional in having plural forms with shifted stress: omicrónes, regimenes, especimenes, and interines. Moreover, nowadays these words are more and more realized with a regular stress pattern: interin becomes interin. For these reasons we feel justified to conclude that our inability to handle these cases within the present analysis is in accordance with their marginal occurence and irregular behaviour.

In comparison to Harris (1983), the present analysis is based on the assumption of a more restrictive relation between extrametricality and the domains of stress assignment and syllabification. That is, these domains coincide with the domain of the PC. Furthermore, the present analysis has a number of empirical advantages over that of Harris (1983) - see for instance the cases in (16), (17), and (23). By assuming a somewhat richer lexical model (34), in which pluralization is assigned to a later level than the level of word stress, we can account for the stress neutrality of pluralization in a more insightful way than Harris could. The lexical model itself can be motivated by stress-independent evidence.

In the final part of this article, we will show that our analysis of Spanish stress, with a few language-specific refinements, is also capable of handling the stress pattern of Italian, a language closely related to Spanish.

\section{Stress in Italian}

Relatively few publications have been devoted to Italian word stress (exceptions being Saltarelli (1970), Vogel (1977), Den Os (1982), Saltarelli (1983)). In the literature, rather divergent positions are taken with respect to the degree of predictability of main strcss. Saltarclli's (1970) claim that main stress is completely (phonologically) predictable from vowel length has been refuted convincingly by Di Pietro (1971) and Vogel (1977). According to Vogel, main stress is largely unpredictable, whereas vowel length depends both on syllable structure and stress.

In spite of the occurrence of minimal pairs like áncora 'anchor', ancóra 'still', we reject the view that the position of main stress is completely unpredictable. It will be shown that extrametricality helps to constrain the type of stress patterns in Italian. That is, the number and position of stress diacritics will be constrained, reducing lexical arbitrariness. 
The following generalizations hold for the potential positions of main stress in Italian words:

(1) In words ending in a class marker (an inflectional suffix, $-o,-i,-a,-e$ indicating gender and/or number) main stress most frequently falls on the penult (mattina 'morning'); otherwise it falls on the antepenult (távola 'table').

(2) In words missing a $C M$, but ending in a vowel, main stress falls on the ultimate syllable (papá 'dad', caffé 'coffee', virtú 'virtue').

(3) In words missing a $\mathrm{CM}$, and ending in a consonant, main stress falls on the penult (revólver), or on the antepenult (féstival), and only incidentally on the ultima (elisir 'elixer').

This means that the main stress is always on one of the last three syllables. Words like mándorla 'almond', ácanto 'acanthus', Ótranto, Lépanto, Táranto (names of towns), and pólizza 'little note', with a skipped heavy penult, do occur, though they are rare. The words mentioned in the third generalization form a very limited class (about $0.5 \%$ of 43,506 words, cf. Alinei (1962)). Words belonging to this class are most frequently stressed, on the penult or antcpenult: referéndum, ultimátum, revólver, álbum, cáos 'chaos', lápis 'pencil', féstival, álcool 'alcohol', ánanas 'pineapple'. Final stress is very rare for this class, e.g. elisir, bazár, zenit. In modern Italian these words are increasingly realized with the stress shifted to the penult or antepenult. The original forms festivál, camión 'truck', cognác 'brandy', are nowadays loosing ground to féstival, cámion, cógnac (Saltarelli (1970)).

Words missing a $\mathrm{CM}$, the groups (2) and (3), remain unchanged in the plural. Words ending in a $\mathrm{CM}$, group (1), have stable stress patterns within all forms; this can be shown by varying the $\mathrm{CM}$ with gender and number: stúpido-stúpida 'stupid $\mathrm{m} / \mathrm{f}$ ', távola-távole 'table(s)'. CM's can never be stressed themselves.

The restriction of occurrence of main stress to the last three syllables and the predominant character of stress on the penult indicate for Italian a binary, left-dominant stress rule operating from right to left, and a right branching w-s labelled word tree. In this respect Italian and Spanish are similar. In contrast to Spanish, however, heavy penults can be skipped in Italian (mándorla), and furthermore, final stress is consonant-final words is rare. From this it appears that Italian, in contrast to Latin and Spanish, is not quantity-sensitive, see (39). 


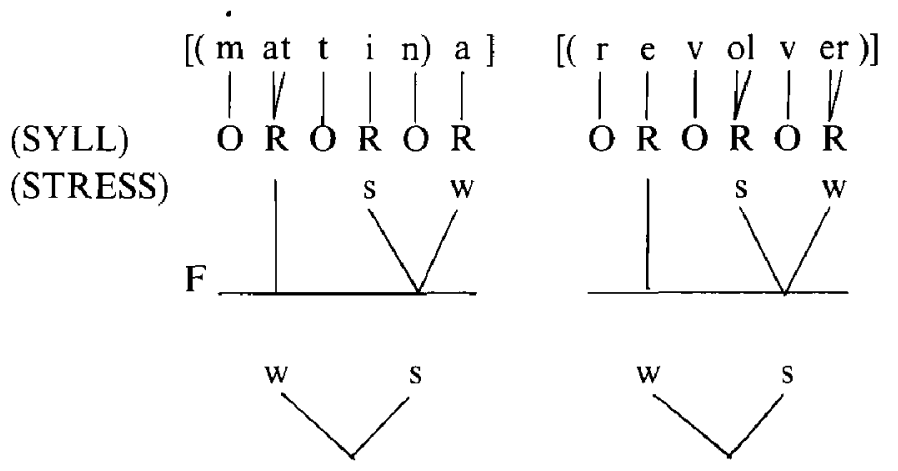

A second difference with Spanish is the presence of consonant-final words with stress on the antepenult (féstival, etc.), some of which have replaced the original forms with final stress. In Spanish we find the contrary tendency, viz. regularization of consonant-final words stressed on the antepenult by a shift to the penult or even the ultima: régimen, interin have as popular variants regimen, interin (Harris (1983: 132)).

We ascribe these differences between Spanish and Italian to the types of extrametrical units that are allowed. In Spanish these are segments, as we concluded earlier, whercas in Italian these are cntire rimes. We assume extrametricality to be assigned by rule in the presence of the $[+E]$ diacritic on the stem.

(40) If the stem carries [+E], mark as extrametrical rimes within the stem and immediately adjacent to the stem.

The presence of $[+\mathrm{F}]$ on the stems (festival), (tavol), (mandorl) will then automatically result in correct antepenultimate stress.

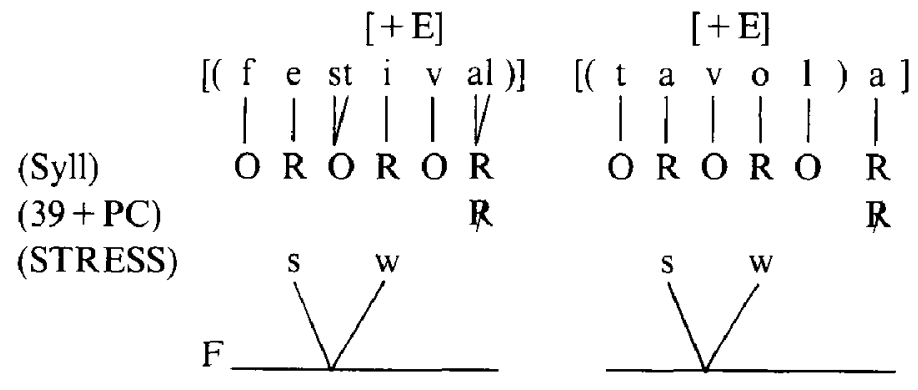




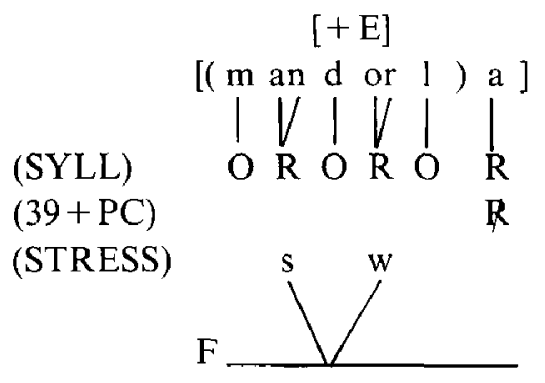

Words ending in a vowel which is not a $\mathrm{CM}$ will be redundantly assigned a foot on the last syllable by a rule similar to the one Harris proposes for Spanish (13). This rule applies to caffé, virtú, etc. From the fact that $-u$ cannot be a $\mathrm{CM}$ in Italian it correctly follows that all words ending in $-u$ must be stressed on the final syllable. The very small number of consonant-final words with antepenultimate stress will have to be handled with lexically supplied feet on their final syllables, as in bazar.

\section{Conclusions}

By adopting principles of stress assignment from metrical theory, Harris (1983) managed to analyse Spanish stress in quite an insightful way. The universally available notion of extrametricality, specified for Spanish as segment extrametricality, was shown to have a considerable explanatory value; it helped to reduce the arbitrary use of stress diacritics that'almost all earlier analyses (e.g. Harris (1969)) made use of. Harris, however, did diverge from Hayes' (1981) restrictive interpretation of extrametricality by having the PC refer to morphological domains, instead of the domain of the stress rule itself.

In the analysis of Spanish stress presented above it was demonstrated that Hayes' interpretation is correct. A rule assigning extrametricality to segments in the presence of a diacritic on stems was formulated. This rule fixes the maximal units of extrametrical material as segments in a language-specific manner. On the one hand, this analysis allows us to allocate lexical diacritics at their proper level, i.e. the stem, where syllable-dependent information like (rime)segment extrametricality is not be available since syllabification is a word level process. On the other hand, the proposed rule enables us to effectuate the diacritic property on the proper syllable and stress relevant level, 
i.e. the word. The present analysis of Spanish stress avoids unnecessarily confounding stem-bound lexical markings and word-bound stress assignment with respect to the PC. The analysis proposed here proved to be succesfully extendable to Italian by varying the parameters of quantity sensitivity and units of extrametricality.

\section{References}

Alinei, M., 1962. Dizionario inverso Italiano; con indici e liste di frequenza delle terminazioni. The Hague-Paris: Mouton.

Archangeli, D., 1984. Underspecification in Yawelmani phonology. MIT. (Ph.D. dissertation.)

Den Os, E., 1982, Extrametricaliteit en Italiaanse klemtoon. Amsterdam. (Unpublished M.A. thesis.)

Di Pietro, R.J., 1971. Review of Saltarelli's (1970) A phonology of Italian in a generative grammar. Language 47, 718-730.

Franks, S., 1985. Extrametricality and stress in Polish. Linguistic Inquiry 16, 144-151.

I Ialle, M. and J.R. Vergnaud, forthcoming. Grids and trees: an essay on stress.

Hammond, D.L., 1977. Word formation in generative grammar: Spanish derivational morphology. Washington, DC: Georgetown University. (Ph.D. dissertation.)

Harris, J.W., 1969. Spanish phonology. MIT. (Ph.D. dissertation.)

Harris, J.W., 1977. Remarks on diphthongization in Spanish. Lingua 41, 261-305.

Harris, J.W., 1980. Nonconcatenative morphology and Spanish plurals. Journal of Linguistic Research 1, 15-30.

Harris, J.W, 1983. Syllable structure and stress in Spanish. Cambridge, MA: MIT Press.

Hayes, B., 1981. A metrical theory of stress rules. Indiana University Linguistic Club.

Hayes, B., 1982. Extrametricality and English Stress. Linguistic Inquiry 13, 227-276.

Hayes, B. and S. Puppel, 1985. On the rhythm rule in Polish. In: H. van der Hulst and N. Smith (eds.), Advances in nonlinear phonology, 59-81. Dordrecht: Foris.

Hooper, J.B. and T. Terrell, 1976. Stress assignment in Spanish: a natural generative analysis. Glossa 10, 64-110.

Jaeggli, O., 1980. Spanish diminutives. In: F.H. Nuessel, Jr. (ed.), Contemporary studies in Romance languages, 142-158. Indiana University Linguistic Club.

Kiparsky, P., 1979. Metrical structure assignment is cyclic. Linguistic Inquiry 10, 421-441.

Kiparsky, P.. 1982. From cyclic phonology to lexical phonology. In: H. van der Hulst and N. Smith (eds.), The structure of phonological representations, Vol. I, 131-175. Dordrecht: Foris.

Liberman, M.Y. and A. Prince, 1977. On stress and linguistic rhythm. Linguistic Inquiry 8, 249-336.

Otero, C.P., 1985. A unified metrical account of Spanish stress. University of California at Los Angeles. (Unpublished manuscript.)

Saltarelli, M., 1970. A phonology of Italian in a generative grammar. The Hague: Mouton.

Saltarelli, M., 1983. The mora unit in Italian phonology. In: W. U. Dressler (ed.), Folia Linguistica Tomus XVII, 7-24. The Hague: Mouton.

Vogel, I., 1977. The syllable in phonological theory: with special reference to Italian. Stanford University. (Ph.D. dissertation.)

Whitley, S., 1976. Stress in Spanish: two approaches. Lingua 39, 301-332. 